\title{
Saliva in the Diagnosis of COVID-19
}

\author{
COVID-19’un Tanısında Tükürük
}

\author{
(D) Elmas Pınar KAHRAMAN KILBAŞ ${ }^{1}$, (10 Mustafa ALTINDiş̧² \\ ${ }^{1}$ Fenerbahçe University, Vocational School of Health Services, Medical Laboratory Techniques, istanbul, Turkey \\ 2Sakarya University Faculty of Medicine, Department of Clinical Microbiology, Sakarya, Turkey
}

\section{Abstract}

The use of saliva samples for the diagnosis of severe acute respiratory syndrome-Coronavirus-2 (SARS-CoV-2) provides several advantages over the use of nasopharyngeal (NP) swabs, such as comfort, ease of self-collection, less use of personal protective equipment, and protection of healthcare personnel from transmission. This review included current studies using saliva samples for the detection of SARS-CoV-2, comparing its sensitivity, cycle threshold, and specificity with those of NP swab. In the literature, the sensitivity rates of saliva samples in the diagnosis of SARS-CoV-2 ranged from $70 \%$ to $98 \%$. Despite different opinions, we concluded that saliva is a reliable sample for the detection of SARS-CoV-2. However, studies with large samples and comparing different diagnostic methods are needed to reach precise and reliable results and include saliva collection in diagnostic guidelines.

Keywords: Saliva, COVID-19, SARS-CoV-2, self-collection, pandemic

\section{Öz}

Şiddetli akut solunum yolu sendromu Koronavirüs-2'nin (SARS-CoV-2) teşhisi için tükürük örneklerinin kullanımı, nazofaringeal sürüntülere kıyasla daha konforlu toplanması, kendi kendine toplama kolaylığı ve kişisel koruyucu ekipmanın daha az kullanımı ve sağlık personelinin kontaminasyondan korunması gibi çeşitli avantajlar sağlar. Çalışmamıza, SARS-CoV-2'nin saptanması için tükürük örneklerinin duyarlılık, döngü eşiği ve özgüllüklerini nazofaringeal sürüntüyle karşılaştıran güncel çalışmaları dahil ettik. Literatürdeki çalışmalarda tükürük örneklerinin SARS-CoV-2 tanısında duyarlılık oranlarının \%70 ile \%98 arasında olduğu bildirilmiştir. Birçok farklı görüşe rağmen, tükürüğün SARS-CoV-2'nin tespiti için güvenilir bir örnek olduğu sonucuna vardık. Ancak, kesin ve güvenilir sonuçlara ulaşmak ve tanı kılavuzlarına COVID-19 tanısında tükürük numunelerini dahil etmek için geniş örneklemlerle ve farklı tanı yöntemlerini karşılaştıran çalışmalara intiyaç vardır.

Anahtar Kelimeler: Tükürük, COVID-19, SARS-CoV-2, kendi kendine örnek alma, pandemi

\section{Introduction}

\section{COVID-19 Pandemic}

The Coronavirus disease-2019 (COVID-19) is a fairly common acute infectious respiratory illness caused by with the novel severe acute respiratory syndrome-Coronavirus-2 (SARS-CoV-2).
It has caused major disruptions in the daily life of the majority of the world's population by seriously threatening public health and society socially and economically. It was first detected in Wuhan, China, in December 2019 and later became a pandemic. As of November 23, 2020, 58,229,138 new confirmed cases and $1,382,106$ deaths were reported ${ }^{[1]}$.

Cite this article as: Kahraman Kılbaş EP, Altındiş M. Saliva in the Diagnosis of COVID-19: A Review. Mediterr J Infect Microb Antimicrob. 2021;10:9. 
According to current clinical studies, some infected individuals may be asymptomatic at all, some people have mild symptoms, and others require hospital treatment. The most common symptoms of COVID-19 are high fever, cough, sore throat, headache, muscle pain, and shortness of breath, although recent reports include diarrhea, conjunctivitis, loss of sense of taste or smell, skin rash, or discoloration of the fingers or toes. Chest pain or feeling of compression in the chest and loss of speech or movement have also been reported ${ }^{[1,2]}$. Patients who are asymptomatic are not considered in the present diagnostic criteria of countries. These patients can act as reservoirs and contribute to the interpersonal spread of the disease.

\section{COVID-19 Diagnosis}

The classical diagnosis of COVID-19 is normally made by qualitative reverse transcription-quantitative polymerase chain reaction (RT-qPCR) to detect virus ribonucleic acid (RNA) from nasopharyngeal (NP) and oropharyngeal (OP) swabs or sputum. Moreover, chest X-ray imaging, showing multilobar groundglass opacities with peripheral, asymmetric, and posterior distribution, may be a practical diagnostic tool for detecting bilateral pneumonia ${ }^{[3]}$.

Worryingly, the viral RNA remains positive and relapses in some patients even 13 days after hospital discharge, suggesting that some patients may not develop immunity to SARS-CoV- $2^{[4]}$. On March 19, 2020, the U.S. Food and Drug Administration approved a serology antibody test as a point of care test for the detection of immunoglobulin $\mathrm{G}(\mathrm{lg} \mathrm{G})$ and $\lg \mathrm{M}$.

\section{Saliva in COVID-19 Diagnosis}

In one study, although SARS-CoV-2 RNA was identified in 32\% of OP swabs, it was used more often than NP swabs in China to detect COVID-19 infection ${ }^{[5]}$. On March 19, 2020, the World Health Organization (WHO) recommended the use of both upper (i.e., NP and OP swabs) and lower [i.e., sputum, bronchoalveolar lavage (BAL), or endotracheal aspirate] respiratory samples for COVID-19 diagnosis. Additionally, upper respiratory tract samples may not detect early-stage viral infections, and collection of lower respiratory tract samples improves the biosecurity risk of aerosol-droplet-borne infections to healthcare professionals. However, SARS-CoV-2 RNA was found in the serum of only $15 \%$ of patients hospitalized for pneumonia, and SARS-CoV-2 RNA was detected in the feces of $55 \%$ of patients ${ }^{[6,7]}$. Various clinical studies have stated that $87 \%, 91.6 \%$, and $100 \%$ of patients with COVID-19 were positive for virus RNA in the saliva ${ }^{[8-10]}$. This suggests that saliva can serve as an exemplary source for the diagnosis of a potent SARS-CoV-2.

Saliva is an appealing secretion for the detection of SARS-CoV-2 because it is noninvasive, accessible, and inexpensive, enables self-collection, and has the ability to "reflect" systemic and local diseases ${ }^{[11]}$. Saliva may contain proinflammatory cytokines, chemokines, matrix metalloproteinases, mitochondrial and genomic deoxyribonucleic acid, bacteria, SARS-CoV and SARS-CoV-2, SARS-CoV antibodies, miRNA, and extracellular vesicles $^{[12,13]}$. In addition, saliva can be stored at $-80 \geq^{\circ} \mathrm{C}$ for a few years without deterioration ${ }^{[14]}$. Therefore, it may be valuable to collect saliva samples throughout the disease course in COVID-19 patients. Saliva can be useful both to diagnose the presence of COVID-19 infection and to identify and monitor immune development against the virus.

Saliva samples have significant logistical advantages over commonly used NP swabs in the detection of COVID-19. It is argued that saliva self-collection is painless for individuals and, more importantly, reduces the risk of viral exposure by eliminating close contact with examiners ${ }^{[15]}$.

This review aimed to evaluate studies using saliva to detect SARS-CoV-2 during the COVID-19 outbreak.

\section{Methods}

To clarify information about saliva samples used in the diagnosis of COVID-19, articles indexed in the NCBI database, WHO COVID-19 global database, and Centers for Disease Control and Prevention COVID-19 transmission web pages were reviewed. This review included articles that provide basic literature on the diagnostic accuracy and sensitivity of saliva samples used in the diagnosis of COVID-19. For the literature search, the following terms and syntax were used: "SARS Coronavirus," "COVID-19", and "saliva in COVID-19 diagnosis". Pre-print and full-text articles were also included. The citation chain for each article to be included was also examined. Publications that did not compare saliva sample results with RT-PCR analysis of NP swabs and articles with unavailable full text were excluded.

\section{Literature Review}

In the past years, among RNA viruses, saliva diagnostic tests for Zika are well designed ${ }^{[16,17]}$. A series of saliva-based detection methods was reported for the detection of Ebola virus ${ }^{[18]}$. The presence of significant amounts of viral RNA in the saliva of 17 patients infected with SARS was also definitively demonstrated ${ }^{[19]}$.

In Hong Kong, saliva samples were collected in an average of two days after hospitalization from a total of 12 patients with PCRconfirmed COVID-19 infection on February 2020. COVID-19 was detected in the first saliva sample of 11 patients (91.7\%). In 33 patients whose NP swabs were negative for COVID-19, all saliva samples also tested negative ${ }^{[9]}$. 
A meta-analysis study that included five studies published in April 2020 reported 91\% sensitivity for saliva tests and 98\% for NP swab tests in patients with confirmed COVID-19 ${ }^{[20]}$.

Yokota et al. ${ }^{[15]}$ reported that NP swabs and saliva samples have $86 \%$ and $92 \%$ sensitivity and $99.93 \%$ and $99.96 \%$ specificity to detect COVID-19, respectively (Figure 1).

In November 2020, Aita et al. ${ }^{[21]}$ conducted rRT-PCR of NP swabs and saliva samples and reported that these samples were both positive in seven and negative in 35 of 43 patients. In one patient, the saliva sample was positive and the NP swab was negative.

Byrne et al. ${ }^{[22]}$ reported that $12(10.9 \%)$ saliva and $14(12.7 \%)$ nasal and throat swab samples of 110 patients were positive for SARS-CoV-2 RNA, and the viral load for all samples ranged from 36 to $3.3 \times 10^{6}$ copies $/ \mathrm{ml}$, with no significant difference between them (Figure 2a). Wyllie et al. ${ }^{[23]}$ investigated the mean virus titers in 46 NP swabs and 37 saliva samples and found that the mean virus titers of saliva samples were approximately five times higher than those of NP swabs (Figure 2b). In general, higher SARS-CoV-2 titers were found in saliva samples than in NP swabs from patients hospitalized for COVID-19.

In November 2020, Altawalah et al. ${ }^{[24]}$ found that $38.61 \%$ of 891 patients had positive and $61.39 \%$ had negative NP swabs, but saliva samples of $34.23 \%$ were positive and those of $65.77 \%$ were negative for SARS-CoV-2. In addition, the diagnostic sensitivity (a) sensitivity
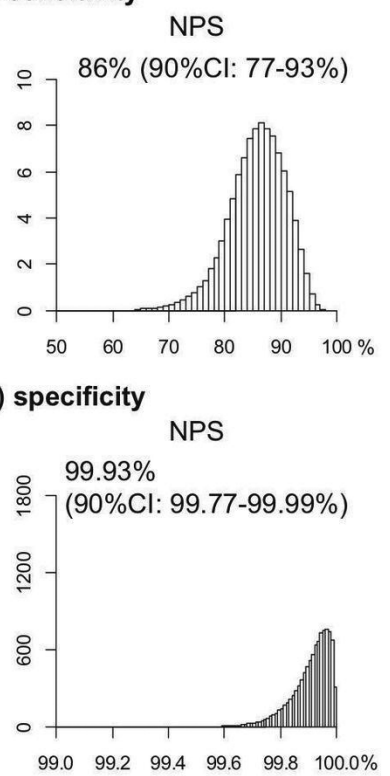

(b) specificity
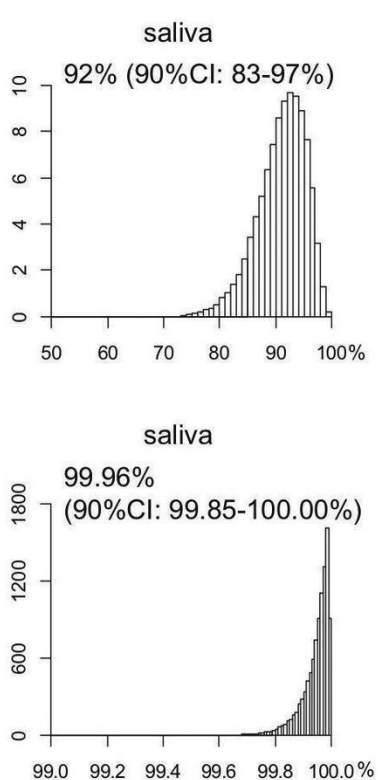

Figure 1. Nasopharyngeal swab and saliva testing showed sensitivity and specificity to the detection of severe acute respiratory syndrome-Coronavirus-2 (Yokota et al. ${ }^{[15]}$ )

$\mathrm{Cl}$ : Confidence interval and specificity of RT-PCR for the diagnosis of COVID-19 in the saliva were $83.43 \%$ and $96.71 \%$, respectively.

Vogels et al. ${ }^{[25]}$ developed Saliva Direct, which received an emergency use permit from the US Food and Drug Administration on August 15,2020. In this method, samples were tested by RT-qPCR by replacing the nucleic acid extraction with a simple proteinase $\mathrm{K}$ and heat treatment step. Saliva Direct is reported to have high sensitivity with a detection limit of 6-12 SARS-CoV-2 copies/MI. In this study conducted with 3,779 NBA players, there were $89.5 \%$ positive and $>99.9 \%$ negative test agreements in saliva samples.

Zhu et al. ${ }^{[26]}$ reported that saliva has sensitivity and specificity of $86.4 \%$ and $97.0 \%$, respectively, when compared with NP and OP swabs.

In the current diagnostic tests for SARS-CoV-2, NP swab sampling requires the use of personal protective equipment that is limited, inconvenient for the patient, and reduces clinical efficacy; therefore, certain studies used different specimens. Table 1 shows some of the studies that have evaluated the diagnostic performance of sputum, nasal, BAL, saliva, OP, NP,
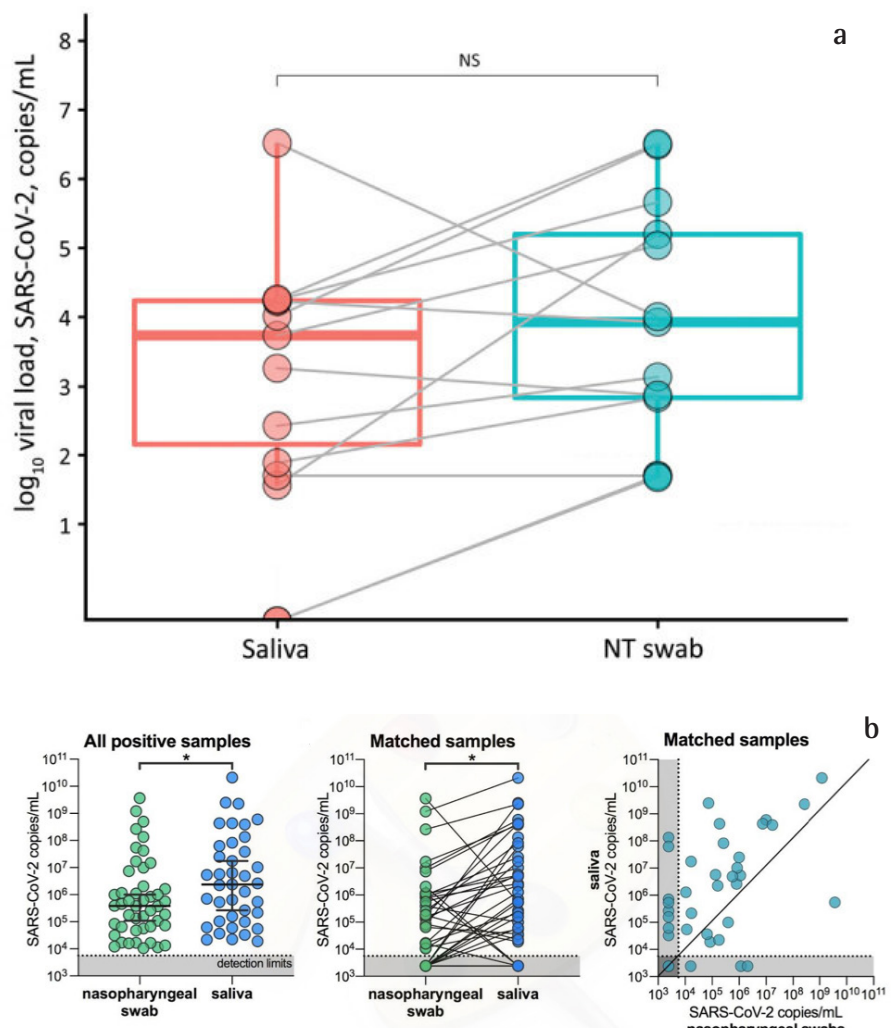

Figure 2. Comparison of the viral load between saliva samples and nasal, nasopharyngeal, and throat swab samples. (a) Byrne et al. ${ }^{[22]}$; b) Wyllie et al. ${ }^{[23]}$

SARS-CoV-2: Severe acute respiratory syndrome-Coronavirus-2 
and tongue samples. As shown in the table, the sensitivities of saliva, sputum, nasal, and middle turbinate (MT) samples are $>90 \%$, and saliva samples showed high specificity.

In April 2020, Tu et al. ${ }^{[27]}$ compared tongue, anterior nose, and MT samples collected by the patient for the diagnosis of SARSCoV-2 with NP swabs collected by healthcare professionals. The sensitivities of patient-collected tongue, nasal, and MT samples to detect SARS-CoV-2 were 89.8\%, 94.0\%, and 96.2\%, respectively, and the corresponding correlation coefficients were $0.48,0.78$, and 0.86 , respectively, compared with NP swab at the cycle threshold values of these samples. It would be beneficial to carry out such studies on saliva samples collected by the patient at their homes. However, disadvantages such as incorrect collection of samples by the patient and higher risk of contamination should be considered (Table 2).

\section{Saliva Sample Collection}

Collecting saliva samples and using it in the diagnosis of COVID-19 may enable more accessible and comfortable tests, especially for children. The application of this collection method requires a consistent supply of an acceptable sample collection device that can be included in laboratory workflows. In this regard, containers and funnels were developed by various manufacturers for collecting saliva.

This method allows patients to easily obtain samples at home and deliver them to healthcare personnel without going to hospitals, which are high-risk areas. It also allows reduction of workload and transmission risk for healthcare personnel.

However, this method will require a sufficient number of assays and laboratory validation as a diagnostic test. In addition, SARS-CoV was reported to infect epithelial cells in the salivary gland duct of Rhesus monkeys ${ }^{[33]}$. Therefore, the presence of COVID-19 in the saliva of patients suggests the possibility of salivary gland infection. However, saliva samples contain not only secretion from the salivary glands but also secretions from the lungs through the cilia descending from the NP or covering the airways ${ }^{[33]}$. More studies with larger samples are needed to detect COVID-19 in saliva.

Table 1. Sensitivity and specificity of different clinical samples used in the diagnosis of Coronavirus disease-2019

\begin{tabular}{|c|c|c|c|c|}
\hline Study & Sample characteristics & Specimen type & Sensitivity & Specificity \\
\hline Altawalah et al. ${ }^{[24]}$ & $\begin{array}{l}891 \text { patients with suspected } \\
\text { COVID-19 }\end{array}$ & Saliva & $83.43 \%$ & $96.71 \%$ \\
\hline Zhu et al. ${ }^{[26]}$ & 944 patients & Saliva & $86.4 \%$ & $97.0 \%$ \\
\hline \multirow[t]{4}{*}{ Tu et al. ${ }^{[27]}$} & $\begin{array}{l}\text { Patients aged } 15 \text { months to } 94 \text { years } \\
\text { old, }\end{array}$ & Nasal, NP, tongue & $\begin{array}{l}\text { Tongue } 89.8 \% \text {, nasal 94\%, and MT } \\
96.2 \%\end{array}$ & - \\
\hline & $\begin{array}{l}501 \text { patients with tongue and NP } \\
\text { samples, }\end{array}$ & & & \\
\hline & $\begin{array}{l}498 \text { patients with nasal and NP } \\
\text { samples, and }\end{array}$ & & & \\
\hline & 504 patients with MT and NP samples & & & \\
\hline Wang et al. ${ }^{[28]}$ & $\begin{array}{l}353 \text { patients (192 outpatients; } 161 \\
\text { inpatients) }\end{array}$ & $\mathrm{NP}$ and $\mathrm{OP}$ & OP $32 \%$ and NP $63 \%$ & - \\
\hline Böger et al. ${ }^{[29]}$ & 388 patients (meta-analysis study) & Sputum & $97.2 \%$ & - \\
\hline
\end{tabular}

COVID-19: Coronavirus disease-2019, MT: Middle turbinate, NP: Nasopharyngeal, OP: Oropharyngeal

Table 2. Sensitivity and specificity of saliva samples used in the diagnosis of Coronavirus disease-2019

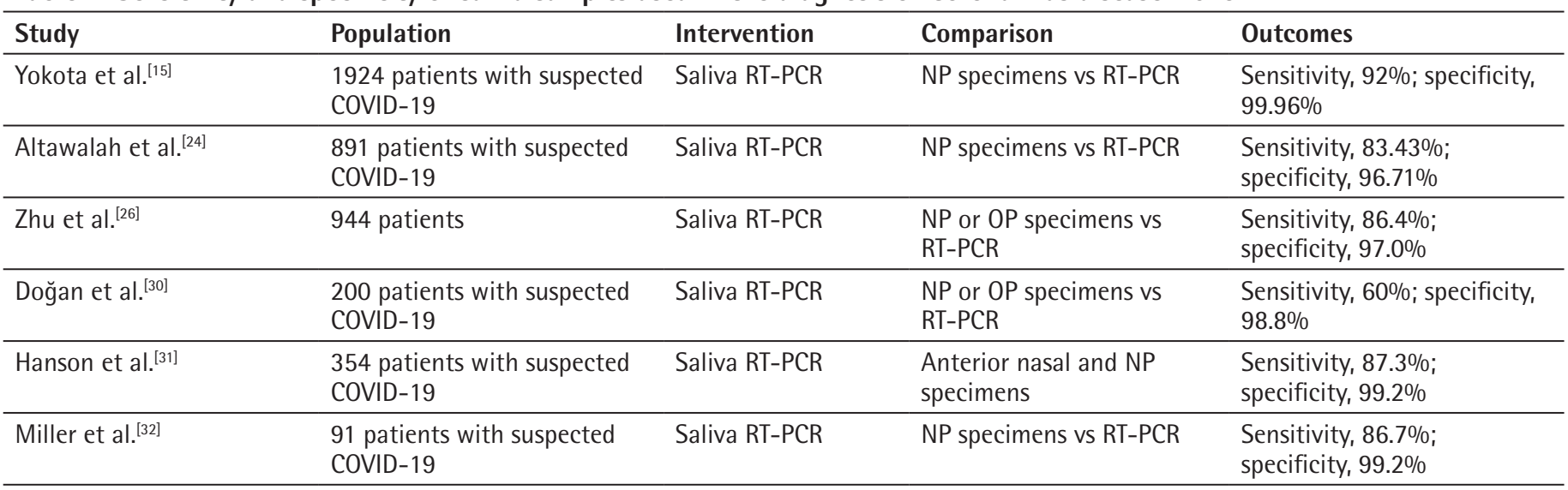

COVID-19: Coronavirus disease-2019, RT-PCR: Reverse transcription-quantitative polymerase chain reaction, NP: Nasopharyngeal, OP: Oropharyngeal 


\section{Conclusion}

Saliva collection is a noninvasive procedure that does not cause discomfort to the patient and allows patients to easily apply low-cost self-sampling techniques at home and thereby prevent healthcare personnel from having close contact with the patient and exposure to the pathogen. However, saliva collection needs to be optimized appropriately to reduce test errors ${ }^{[34]}$.

For the detection of SARS-CoV-2 infection using saliva samples, the time period that allows detection of SARS-CoV-2 in the saliva should be well defined, as the viral load in the saliva is reported to be high during the first few days of infection, followed by a decrease in the viral load ${ }^{[8]}$.

For further investigation, studies should be conducted with a large number of NP, OP, and saliva samples that are molecularly confirmed. Considering the positive and negative aspects of saliva samples in the diagnosis of COVID-19, each country and organization should develop unique screening methods. Saliva samples can be helpful during a pandemic because speed in diagnosis is important and tests may be repeated.

\section{Ethics}

Peer-review: Externally and internally peer-reviewed.

\section{Authorship Contributions}

Concept: M.A., Design: M.A., Data Collection or Processing: E.P.K.K., Analysis or Interpretation: E.P.K.K., M.A., Literature Search: E.P.K.K., Writing: E.P.K.K., M.A.

Conflict of Interest: No conflict of interest was declared by the authors.

Financial Disclosure: The authors declared that this study received no financial support.

\section{References}

1. WHO, COVID-19 Dashboard. Available from: https://covid19.who.int Accessed date: 23.11 .2020

2. Lauer SA, Grantz KH, Bi Q, Jones FK, Zheng Q, Meredith HR, Azman AS, Reich NG, Lessler J. The Incubation Period of Coronavirus Disease 2019 (COVID-19) From Publicly Reported Confirmed Cases: Estimation and Application. Ann Intern Med. 2020;172:577-82.

3. ACR Recommendations for the Use of Chest Radiography and Computed Tomography (CT) for Suspected COVID- 19 Infection; American College of Radiology: Reston, VA, USA, March 11 2020. Available from: https:// www.acr.org/Advocacy-and-Economics/ACR-Position-Statements/ Recommendations-for-Chest-Radiography-and-CT-for-SuspectedCOVID19-Infection

4. Lan L, Xu D, Ye G, Xia C, Wang S, Li Y, Xu H. Positive RT-PCR Test Results in Patients Recovered From COVID-19. JAMA. 2020;323:1502-3.

5. Wang W, Xu Y, Gao R, Lu R, Han K, Wu G, Tan W. Detection of SARS-CoV-2 in Different Types of Clinical Specimens. JAMA. 2020;323:1843-4.
6. Huang C, Wang Y, Li X, Ren L, Zhao J, Hu Y, Zhang L, Fan G, Xu J, Gu X, Cheng Z, Yu T, Xia J, Wei Y, Wu W, Xie X, Yin W, Li H, Liu M, Xiao Y, Gao H, Guo L, Xie J, Wang G, Jiang R, Gao Z, Jin Q, Wang J, Cao B. Clinical features of patients infected with 2019 novel coronavirus in Wuhan, China. Lancet. 2020;395:497-506.

7. Wu Y, Guo C, Tang L, Hong Z, Zhou J, Dong X, Yin H, Xiao O, Tang Y, Qu $X$, Kuang L, Fang $X$, Mishra N, Lu J, Shan H, Jiang G, Huang X. Prolonged presence of SARS-CoV-2 viral RNA in faecal samples. Lancet Gastroenterol Hepatol. 2020;5:434-5.

8. To KK, Tsang OT, Leung WS, Tam AR, Wu TC, Lung DC, Yip CC, Cai JP, Chan JM, Chik TS, Lau DP, Choi CY, Chen LL, Chan WM, Chan KH, Ip JD, Ng AC, Poon RW, Luo CT, Cheng VC, Chan JF, Hung IF, Chen Z, Chen H, Yuen KY. Temporal profiles of viral load in posterior oropharyngeal saliva samples and serum antibody responses during infection by SARS-CoV-2: an observational cohort study. Lancet Infect Dis. 2020;20:565-74.

9. To KK, Tsang OT, Yip CC, Chan KH, Wu TC, Chan JM, Leung WS, Chik TS, Choi CY, Kandamby DH, Lung DC, Tam AR, Poon RW, Fung AY, Hung IF, Cheng VC, Chan JF, Yuen KY. Consistent Detection of 2019 Novel Coronavirus in Saliva. Clin Infect Dis. 2020;71:841-3.

10. Azzi L, Carcano G, Gianfagna F, Grossi P, Gasperina DD, Genoni A, Fasano M, Sessa F, Tettamanti L, Carinci F, Maurino V, Rossi A, Tagliabue A, Baj A. Saliva is a reliable tool to detect SARS-CoV-2. J Infect. 2020;81:45-50.

11. Pfaffe T, Cooper-White J, Beyerlein P, Kostner K, Punyadeera C. Diagnostic potential of saliva: current state and future applications. Clin Chem. 2011;57:675-87.

12. Buduneli N, Kinane DF. Host-derived diagnostic markers related to soft tissue destruction and bone degradation in periodontitis. J Clin Periodontol. 2011;38:85-105.

13. Kinane DF, Preshaw PM, Loos BG; Working Group 2 of Seventh European Workshop on Periodontology. Host-response: understanding the cellular and molecular mechanisms of host-microbial interactions--consensus of the Seventh European Workshop on Periodontology. J Clin Periodontol. 2011;38:44-8.

14. Chiappin S, Antonelli G, Gatti R, De Palo EF. Saliva specimen: a new laboratory tool for diagnostic and basic investigation. Clin Chim Acta. 2007;383:30-40.

15. Yokota I, Shane PY, Okada K, Unoki Y, Yang Y, Inao T, Sakamaki K, Iwasaki S, Hayasaka K, Sugita J, Nishida M, Fujisawa S, Teshima T. Mass screening of asymptomatic persons for SARS-CoV-2 using saliva. Clin Infect Dis. 2020:1388.

16. Khurshid Z, Zafar $M$, Khan $E_{1}$ Mali $M$, Latif M. Human saliva can be a diagnostic tool for Zika virus detection. J Infect Public Health. 2019;12:6014.

17. Gorchakov R, Berry RM, Patel SM, El Sahly HM, Ronca SE, Murray KO. Optimizing PCR Detection of Zika Virus from Various Body Fluids. Am J Trop Med Hyg. 2019;100:427-33.

18. Niedrig $M$, Patel $P$, El Wahed $A A$, Schädler $R$, Yactayo $S$. Find the right sample: A study on the versatility of saliva and urine samples for the diagnosis of emerging viruses. BMC Infect Dis. 2018;18:707.

19. Wang WK, Chen SY, Liu IJ, Chen YC, Chen HL, Yang CF, Chen PJ, Yeh SH, Kao CL, Huang LM, Hsueh PR, Wang JT, Sheng WH, Fang CT, Hung CC, Hsieh SM, Su CP, Chiang WC, Yang JY, Lin JH, Hsieh SC, Hu HP, Chiang YP, Wang JT, Yang PC, Chang SC; SARS Research Group of the National Taiwan University/National Taiwan University Hospital. Detection of SARSassociated coronavirus in throat wash and saliva in early diagnosis. Emerg Infect Dis. 2004;10:1213-9.

20. Czumbel LM, Kiss S, Farkas N, Mandel I, Hegyi A, Nagy Á, Lohinai Z, Szakács Z, Hegyi P, Steward MC, Varga G. Saliva as a Candidate for COVID-19 Diagnostic Testing: A Meta-Analysis. Front Med (Lausanne). 2020;7:465. Available from: https://www.ncbi.nlm.nih.gov/pmc/articles/PMC7438940/ 
21. Aita $A$, Basso D, Cattelan AM, Fioretto $P$, Navaglia $F$, Barbaro $F$, Stoppa A, Coccorullo E, Farella A, Socal A, Vettor R, Plebani M. SARS-CoV-2 identification and $\lg A$ antibodies in saliva: One sample two tests approach for diagnosis. Clin Chim Acta. 2020;510:717-22.

22. Byrne RL, Kay GA, Kontogianni K, Aljayyoussi G, Brown L, Collins AM, Cuevas $L E$, Ferreira DM, Fraser AJ, Garrod G, Hill $H$, Hughes GL, Menzies $S$, Mitsi E, Owen SI, Patterson El, Williams CT, Hyder-Wright A, Adams ER, CubasAtienzar Al. Saliva Alternative to Upper Respiratory Swabs for SARS-CoV-2 Diagnosis. Emerg Infect Dis. 2020;26:2770-1.

23. Wyllie $A L$, Fourmier J, Casanovas-Massana $A$, Campbell $M$, Tokuyama $M$, Vijayakumar $\mathrm{P}$, Geng B, Muenker MC, Moore AJ, Vogels CBF, Petrone ME, Ott IM, Lu P, Venkataraman A, Lu-Culligan A, Klein J, Earnest R, Simonov M, Datta $R$, Handoko $R$, Naushad N, Sewanan LR, Valdez J, White EB, Lapidus S, Kalinich CC, Jiang X, Kim DJ, Kudo E, Linehan M, Mao T, Moriyama M, Oh JE, Park A, Silva J, Song E, Takahashi T, Taura M, Weizman OE, Wong $P$, Yang Y, Bermejo S, Odio C, Omer SB, Dela Cruz CS, Farhadian S, Martinello RA, Iwasaki A, Grubaugh ND, Ko Al. Saliva is more sensitive for SARSCoV-2 detectionin COVID-19 patients than nasopharyngeal swabs. N Engl J Med. 2020;383:1283-1286. Available from: https://pubmed.ncbi.nlm.nih. gov/32857487/

24. Altawalah $\mathrm{H}$, AlHuraish $\mathrm{F}$, Alkandari WA, Ezzikouri S. Saliva specimens for detection of severe acute respiratory syndrome coronavirus 2 in Kuwait: A cross-sectional study. J Clin Virol. 2020;132:104652.

25. Vogels CBF, Watkins AE, Harden CA, Brackney DE, Shafer J, Wang J, Caraballo C, Kalinich CC, Ott IM, Fauver JR, Kudo E, Lu P, Venkataraman A, Tokuyama M, Moore AJ, Muenker MC, Casanovas-Massana A, Fournier J, Bermejo $S$, Campbell M, Datta R, Nelson A; Yale IMPACT Research Team, Dela Cruz CS, Ko Al, Iwasaki A, Krumholz HM, Matheus JD, Hui P, Liu C, Farhadian SF, Sikka R, Wyllie AL, Grubaugh ND. SalivaDirect: A Simplified and Flexible Platform to Enhance SARS-CoV-2 Testing Capacity. Med (N Y). 2020 Dec 26.

26. Zhu J, Guo J, Xu Y, Chen X. Viral dynamics of SARS-CoV-2 in saliva from infected patients. J Infect. 2020;81:48-50.
27. Tu YP, Jennings R, Hart B, Cangelosi GA, Wood RC, Wehber K, Verma P, Vojta D, Berke EM. Swabs Collected by Patients or Health Care Workers for SARSCoV-2 Testing. N Engl J Med. 2020;383:494-6.

28. Wang $X$, Tan L, Wang $X$, Liu W, Lu Y, Cheng L, Sun Z. Comparison of nasopharyngeal and oropharyngeal swabs for SARS-CoV-2 detection in 353 patients received tests with both specimens simultaneously. Int J Infect Dis. 2020;94:107-9.

29. Böger B, Fachi MM, Vilhena RO, Cobre AF, Tonin FS, Pontarolo R. Systematic review with meta-analysis of the accuracy of diagnostic tests for COVID-19. Am J Infect Control. 2021;49:21-9.

30. Dogan OA, Kose B, Agaoglu NB, Yildiz J, Alkurt G, Demirkol YK, Irvem A, Doganay GD, Doganay L. Does sampling saliva increase detection of SARSCoV-2 by RT-PCR? Comparing saliva with oro-nasopharyngeal swabs. J Virol Methods. 2020;290:114049.

31. Hanson KE, Barker AP, Hillyard DR, Gilmore N, Barrett JW, Orlandi RR, Shakir SM. Self-Collected Anterior Nasal and Saliva Specimens versus Health Care Worker-Collected Nasopharyngeal Swabs for the Molecular Detection of SARS-CoV-2. J Clin Microbiol. 2020;58:e1824-20.

32. Miller $M$, Jansen $M$, Bisignano $A$, Mahoney $S$, Wechsberg $C$, Albanese $N$, Castillo L, Parinas P, Lazarin GA, Jaremko M. Validation of a selfadministrable, saliva-based RT-qPCR test detecting SARS-CoV-2. Preprint. Posted online June 9, 2020. MedRxiv. 1-18. Available from: https://www. medrxiv.org/content/10.1101/2020.06.05.20122721v1.full

33. Sri Santosh T, Parmar R, Anand H, Srikanth K, Saritha M. A Review of Salivary Diagnostics and Its Potential Implication in Detection of Covid-19. Cureus. 2020;12:7708. Available from: https://pubmed.ncbi.nlm.nih.gov/32313785/

34. Bhattarai KR, Kim HR, Chae HJ. Compliance with Saliva Collection Protocol in Healthy Volunteers: Strategies for Managing Risk and Errors. Int J Med Sci. 2018;15:823-31. Available from: https://pubmed.ncbi.nlm.nih. gov/30008593/ 